\title{
Discovery, Diagnosis, and Etiology of Craniofacial Ciliopathies
}

\author{
Elizabeth N. Schock and Samantha A. Brugmann \\ Division of Plastic Surgery, Department of Surgery, and Division of Developmental Biology, \\ Department of Pediatrics, Cincinnati Children's Hospital Medical Center, Cincinnati, Ohio 45229 \\ Correspondence: samantha.brugmann@cchmc.org
}

\begin{abstract}
Seventy-five percent of congenital disorders present with some form of craniofacial malformation. The frequency and severity of these malformations makes understanding the etiological basis crucial for diagnosis and treatment. A significant link between craniofacial malformations and primary cilia arose several years ago with the determination that $\sim 30 \%$ of ciliopathies could be primarily defined by their craniofacial phenotype. The link between the cilium and the face has proven significant, as several new "craniofacial ciliopathies" have recently been diagnosed. Herein, we reevaluate public disease databases, report several new craniofacial ciliopathies, and propose several "predicted" craniofacial ciliopathies. Furthermore, we discuss why the craniofacial complex is so sensitive to ciliopathic dysfunction, addressing tissue-specific functions of the cilium as well as its role in signal transduction relevant to craniofacial development. As a whole, these analyses suggest a characteristic facial phenotype associated with craniofacial ciliopathies that can perhaps be used for rapid discovery and diagnosis of similar disorders in the future.
\end{abstract}

In 2009, Baker and Beales published a review characterizing human ciliopathies. This work detailed known, likely, and possible ciliopathies based on the presentation of nine core phenotypic features: retinitis pigmentosa, polydactyly, situs inversus, mental retardation, agenesis of the corpus callosum, Dandy-Walker malformation, posterior encephalocele, renal cystic disease, and hepatic disease. Using these core characteristics, they identified 15 known ciliopathies and 88 potential ciliopathies (Baker and Beales 2009). Two years later, we analyzed the ciliopathies put forth by Baker and Beales and determined that $\sim 30 \%$ of known or proposed ciliopathies were primarily defined by their cra- niofacial phenotype, which included cleft lip/ palate, increased/decreased midfacial width (hyper-/hypotelorism), small lower jaw (micrognathia), and prematurely fused cranial sutures (craniosynostosis) (Zaghloul and Brugmann 2011).

Much has been learned about ciliopathies in the last 5 years. In this review, we reexamine what is known regarding craniofacial ciliopathies, those ciliopathies defined by their craniofacial phenotype. To do so, we modified the original search methods used by Baker and Beales. We searched the Online Mendelian Inheritance in Man (OMIM) database for any disease that met two requirements: presentation of

Editors: Wallace Marshall and Renata Basto

Additional Perspectives on Cilia available at www.cshperspectives.org

Copyright (C) 2017 Cold Spring Harbor Laboratory Press; all rights reserved; doi: 10.1101/cshperspect.a028258

Cite this article as Cold Spring Harb Perspect Biol 2017;9:a028258 
one of the ciliopathic craniofacial phenotypes (cleft lip/palate, hyper-/hypotelorism, micrognathia, or craniosynostosis) and presentation of two core ciliopathic phenotypes (excluding renal cystic disease and hepatic disease) (Table $1)$. We excluded searches for "cleft lip/palate AND mental retardation" and "hypertelorism AND mental retardation" because these searches resulted in exceedingly large lists that are likely not specific to ciliopathies. In total, we identified more than 400 possible ciliopathies using this unbiased method. We then manually inspected this list of diseases and excluded any syndrome caused by large-scale chromosomal duplication, deletion, or rearrangements, as a specific genetic etiology would be difficult to determine. The genetic cause of the remaining diseases, if known, was examined and lists of known and predicted ciliopathies were generated based on gene function (Tables 2 and 3). Unlike Baker and Beales, who included transcription factors thought to be downstream targets of ciliary signaling, we did not include these, as ciliary function is not dependent on these genes.

Our search identified 26 known ciliopathies defined by craniofacial phenotypes (Table 2). We confirmed 20 previously known craniofacial ciliopathies and reclassified five craniofacial ciliopathies formerly categorized by Baker and Beales as "likely" ciliopathies. Furthermore, our analysis identified one new craniofacial ciliopathy, Hydrolethalus syndrome 2, not previously reported in any search. Within our updated list of known ciliopathies, we found that cleft lip/palate was the most common craniofacial phenotype (Fig. 1A,B), followed by hypertelorism (Fig. 1C), micrognathia (Fig. 1D), craniosynostosis (Fig. 1E), and hypotelorism (Fig. 1C). Interestingly, the most prevalent craniofacial phenotypes were directly associated either widening or deficiencies of the midface (cleft lip/palate, hypertelorism, micrognathia). Finally, we cross-referenced our list of 26 known craniofacial ciliopathies against the seven core ciliopathic phenotypes. This analysis revealed that, within craniofacial ciliopathies, polydactyly most commonly presented in combination with craniofacial phenotypes (Fig. 1F), followed by phenotypes associated with the brain: agenesis of the corpus callosum, Dandy-Walker malformation, posterior encephalocele, and mental retardation.

In addition to our list of "known" craniofacial ciliopathies, we also used our analyses to generate a list of "predicted" craniofacial ciliopathies, disorders that meet the phenotypic criteria, yet do not have a known genetic cause linked to the structure or function of the primary cilia. We identified 25 predicted craniofacial ciliopathies (Table 3). Of the 25 disorders, 13 were previously predicted (Baker and Beales 2009), whereas the remaining 12 were newly classified as predicted craniofacial ciliopathies. Many of these diseases share a striking phenotypic resemblance with known craniofacial ciliopathies, presenting with severe micrognathia, hypertelorism, and cleft lip/palate.

Why Is the Craniofacial Complex So Sensitive to Ciliary Dysfunction?

Primary cilia are ubiquitous organelles that are present on almost every cell type throughout development, yet the phenotypes of ciliopathies are not identical and can be confined to individual organ systems. The craniofacial complex is the primary organ system affected in almost $30 \%$ of ciliopathies. This metric begs the question-what makes the face so sensitive to ciliary dysfunction? There are perhaps two main reasons the face is so sensitive to defects in the primary cilium. First, the face is formed by intricate tissue-tissue interactions between cranial neural crest cells (CNCCs), neuroectoderm, facial ectoderm, and pharyngeal endoderm. Thus, if any one of these tissues requires ciliary function for proper development, the face, as a whole, will be negatively impacted. Second, several of the signaling pathways essential for proper craniofacial patterning require the cilium for signal transduction. In the following sections, we will explain the tissues and signaling pathways required for craniofacial development. Furthermore, we will comment on how ciliary defects can impact facial development. 
Table 1. Pairwise combinations of phenotypes

\begin{tabular}{|c|c|c|c|c|c|}
\hline & $\begin{array}{l}\text { Cleft lip } \\
\text { and/or } \\
\text { palate }\end{array}$ & Hypertelorism & Hypotelorism & Micrognathia & Craniosynostosis \\
\hline $\begin{array}{l}\text { Retinitis pigmentosa }+ \\
\text { polydactyly }\end{array}$ & 1 & 2 & 3 & 4 & 5 \\
\hline $\begin{array}{l}\text { Retinitis pigmentosa }+ \text { mental } \\
\text { retardation }\end{array}$ & $6^{\mathrm{a}}$ & $7^{\mathrm{a}}$ & 8 & 9 & 10 \\
\hline $\begin{array}{l}\text { Retinitis pigmentosa }+ \text { situs } \\
\text { inversus }\end{array}$ & 11 & 12 & 13 & 14 & 15 \\
\hline $\begin{array}{l}\text { Retinitis pigmentosa }+ \\
\text { agenesis of corpus callosum }\end{array}$ & 16 & 17 & 18 & 19 & 20 \\
\hline $\begin{array}{l}\text { Retinitis pigmentosa }+ \\
\text { Dandy-Walker } \\
\text { malformation }\end{array}$ & 21 & 22 & 23 & 24 & 25 \\
\hline $\begin{array}{l}\text { Retinitis pigmentosa }+ \\
\text { posterior encephalocele }\end{array}$ & 26 & 27 & 28 & 29 & 30 \\
\hline $\begin{array}{l}\text { Polydactyly }+ \text { mental } \\
\quad \text { retardation }\end{array}$ & $31^{\mathrm{a}}$ & $32^{\mathrm{a}}$ & 33 & 34 & 35 \\
\hline Polydactyly + situs inversus & 36 & 37 & 38 & 39 & 40 \\
\hline $\begin{array}{l}\text { Polydactyly }+ \text { agenesis of } \\
\text { corpus callosum }\end{array}$ & 41 & 42 & 43 & 44 & 45 \\
\hline $\begin{array}{l}\text { Polydactyly }+ \text { Dandy-Walker } \\
\text { malformation }\end{array}$ & 46 & 47 & 48 & 49 & 50 \\
\hline $\begin{array}{l}\text { Polydactyly }+ \text { posterior } \\
\text { encephalocele }\end{array}$ & 51 & 52 & 53 & 54 & 55 \\
\hline $\begin{array}{l}\text { Mental retardation }+ \text { situs } \\
\text { inversus }\end{array}$ & $56^{\mathrm{a}}$ & $57^{\mathrm{a}}$ & 58 & 59 & 60 \\
\hline $\begin{array}{l}\text { Mental retardation }+ \text { agenesis } \\
\text { of corpus callosum }\end{array}$ & $61^{\mathrm{a}}$ & $62^{\mathrm{a}}$ & 63 & 64 & 64 \\
\hline $\begin{array}{l}\text { Mental retardation }+ \text { Dandy- } \\
\text { Walker malformation }\end{array}$ & $66^{\mathrm{a}}$ & $67^{\mathrm{a}}$ & 68 & 69 & 70 \\
\hline $\begin{array}{l}\text { Mental retardation }+ \\
\text { posterior encephalocele }\end{array}$ & $71^{\mathrm{a}}$ & $72^{\mathrm{a}}$ & 73 & 74 & 75 \\
\hline $\begin{array}{l}\text { Situs inversus }+ \text { agenesis of } \\
\text { corpus callosum }\end{array}$ & 76 & 77 & 78 & 79 & 80 \\
\hline $\begin{array}{l}\text { Situs inversus + Dandy- } \\
\text { Walker malformation }\end{array}$ & 81 & 82 & 83 & 84 & 85 \\
\hline $\begin{array}{l}\text { Situs inversus }+ \text { posterior } \\
\text { encephalocele }\end{array}$ & 86 & 87 & 88 & 89 & 90 \\
\hline $\begin{array}{l}\text { Agenesis of corpus callosum }+ \\
\text { Dandy-Walker } \\
\text { malformation }\end{array}$ & 91 & 92 & 93 & 94 & 95 \\
\hline $\begin{array}{l}\text { Agenesis of corpus callosum }+ \\
\text { posterior encephalocele }\end{array}$ & 96 & 97 & 98 & 99 & 100 \\
\hline $\begin{array}{c}\text { Dandy-Walker malformation } \\
+ \text { posterior encephalocele }\end{array}$ & 101 & 102 & 103 & 104 & 105 \\
\hline
\end{tabular}

"These comparisons could not be evaluated because initial searches for "cleft lip and/or palate AND mental retardation" and "hypertelorism AND mental retardation" were not completed. 
E.N. Schock and S.A. Brugmann

Table 2. Known craniofacial ciliopathies

\begin{tabular}{|c|c|c|c|}
\hline Syndrome & Genes & Phenotypes & $\begin{array}{l}\text { Classification in } \\
\text { Baker and Beales }\end{array}$ \\
\hline Bardet-Beidl syndrome 1 & $B B S 1$ & $1,11,36$ & Known ciliopathy \\
\hline Cranioectodermal dysplasia & IFT43 & 4,5 & Known ciliopathy \\
\hline Ellis-van Crevald syndrome & $E V C, E V C 2$ & $36,46,81$ & Known ciliopathy \\
\hline Joubert syndrome 1 & INPP5E & $34,44,49,69,94$ & Known ciliopathy \\
\hline Joubert syndrome 2 & TMEM216 & $\begin{array}{c}35,41,42,45,46,47,51,52 \\
53,55,65,70,75,91,92,95 \\
96,97,100,101,102,105\end{array}$ & Known ciliopathy $^{\mathrm{a}}$ \\
\hline Joubert syndrome 14 & TMEM237 & 47 & Known ciliopathy $^{\mathrm{a}}$ \\
\hline Meckel syndrome, type I & MKS1 & $\begin{array}{l}41,42,43,44,46,47,48,49 \\
\quad 51,52,53,5491,92,93,94 \\
\quad 96 \\
\quad 97,98,99,101,102,103 \\
104\end{array}$ & Known ciliopathy \\
\hline Meckel syndrome, type II & TMEM216 & 46 & Known ciliopathy $^{\mathrm{a}}$ \\
\hline Meckel syndrome, type III & TMEM67 & $41,46,91$ & Known ciliopathy $^{\mathrm{a}}$ \\
\hline Meckel syndrome, type IV & CEP290 & 46 & Known ciliopathy $^{\mathrm{a}}$ \\
\hline Oral-facial-digital syndrome I & OFD1 & $34,41,44,64$ & Known ciliopathy \\
\hline Oral-facial-digital syndrome IV & TCTN3 & $41,42,44$ & Known ciliopathy $^{\mathrm{a}}$ \\
\hline Oral-facial-digital syndrome $\mathrm{V}$ & DDX59 & 41,42 & Known ciliopathy $^{\mathrm{a}}$ \\
\hline Oral-facial-digital syndrome VI & C5ORF42 & $\begin{array}{l}34,41,42,44,46,47,49 \\
\quad 64,69,91,92,94\end{array}$ & Known ciliopathy $^{\mathrm{a}}$ \\
\hline Oral-facial-digital syndrome IX & Unknown & 46,47 & Known ciliopathy $^{\mathrm{a}}$ \\
\hline $\begin{array}{l}\text { Short-rib thoracic dysplasia } 3 \\
\text { with or without polydactyly }\end{array}$ & DYNC2H1 & 41 & Known ciliopathy \\
\hline $\begin{array}{l}\text { Short-rib thoracic dysplasia } 6 \\
\text { with or without polydactyly }\end{array}$ & NEK11 & 40 & Known ciliopathy $^{\mathrm{a}}$ \\
\hline $\begin{array}{l}\text { Short-rib thoracic dysplasia } 9 \\
\text { with or without polydactyly }\end{array}$ & IFT140 & 1 & Known ciliopathy $^{\mathrm{a}}$ \\
\hline $\begin{array}{l}\text { Short-rib thoracic dysplasia } 13 \\
\text { with or without polydactyly }\end{array}$ & CEP120 & 46,47 & Known ciliopathy $^{\mathrm{a}}$ \\
\hline $\begin{array}{l}\text { Short-rib thoracic dysplasia } 14 \\
\text { with polydactyly }\end{array}$ & KIAA0586 & 41 & Known ciliopathy $^{\mathrm{a}}$ \\
\hline Acrocallosal syndrome & KIF7 & $41,42,46,47,91,92$ & Likely ciliopathy \\
\hline Coach syndrome & $\begin{array}{l}\text { CC2D2A, } \\
\text { TMEM67, } \\
\text { RPGRIP1L }\end{array}$ & $42,52,98$ & Likely ciliopathy \\
\hline Hydrolethalus syndrome 1 & HYLS1 & $41,44,46,49,91,94$ & Likely ciliopathy \\
\hline Mohr syndrome (OFD2) & Unknown & $42,46,47,102$ & Likely ciliopathy \\
\hline $\begin{array}{l}\text { Renal-hepatic-pancreatic } \\
\text { dysplasia }\end{array}$ & NPHP3 & $37,47,82$ & Likely ciliopathy \\
\hline Hydrolethalus syndrome 2 & KIF7 & 41,44 & $\mathrm{~N} / \mathrm{A}$ \\
\hline
\end{tabular}

N/A, Not applicable.

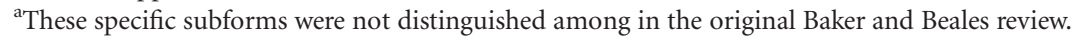

\section{CRANIOFACIAL TISSUES}

The developing craniofacial complex is comprised of distinct prominences that fuse togeth- er to form a recognizable face (Fig. 2). At the midline is a single frontonasal prominence (FNP) that gives rise to the forehead, bridge, and tip of the nose, the philtrum, the medial 
Table 3. Predicted craniofacial ciliopathies

\begin{tabular}{|c|c|c|c|}
\hline Syndromes & Gene & Phenotypes & $\begin{array}{l}\text { Classification in } \\
\text { Baker and Beales }\end{array}$ \\
\hline Acromelic frontonasal dystosis & ZSWIM6 & $41,42,51,52,96,97$ & Likely ciliopathy \\
\hline Opitz GBBB syndrome, type II & SPECC1L & $\begin{array}{l}11,16,17,19,20,22,24 \\
\quad 25,64,69,70,86,91,92 \\
\quad 94,95\end{array}$ & Likely ciliopathy \\
\hline Adams-Oliver syndrome 1 & ARHGAP31 & $64,65,96$ & Potential ciliopathy \\
\hline Carpenter syndrome 1 & $R A B 23$ & 36 & Potential ciliopathy \\
\hline Cerebrofaciothoracic dysplasia & TMCO1 & 64,65 & Potential ciliopathy \\
\hline Dandy-Walker syndrome & Unknown & 91 & Potential ciliopathy \\
\hline Fryns syndrome & Unknown & $64,65,69,70,91,92,94,95$ & Potential ciliopathy \\
\hline Hemifacial microsomia & Unknown & $36,41,51,86,96$ & Potential ciliopathy \\
\hline Johnson neuroectodermal syndrome & Unknown & 34,35 & Potential ciliopathy \\
\hline Marden-Walker syndrome & PIEZO2 & $64,65,69,70,91,92,94,95$ & Potential ciliopathy \\
\hline Oculoauriculofrontonasal syndrome & Unknown & $96,97,99,100,101$ & Potential ciliopathy \\
\hline Oculocerebrocutaneous syndrome & Unknown & 91,96 & Potential ciliopathy \\
\hline Split-hand/foot malformations & Unknown & 34 & Potential ciliopathy \\
\hline $\begin{array}{l}\text { Agenesis of the corpus callosum with } \\
\text { facial anomalies and Robin sequence }\end{array}$ & Unknown & 64,65 & $\mathrm{~N} / \mathrm{A}$ \\
\hline Aicardi syndrome & Unknown & 91 & $\mathrm{~N} / \mathrm{A}$ \\
\hline Baraitser-Winter syndrome 1 & $A C T B$ & 91 & $\mathrm{~N} / \mathrm{A}$ \\
\hline $\begin{array}{l}\text { Craniosynostosis-mental retardation } \\
\text { syndrome of Lin and Gettig }\end{array}$ & Unknown & $35,63,64,65$ & $\mathrm{~N} / \mathrm{A}$ \\
\hline $\begin{array}{l}\text { Dandy-Walker malformation with } \\
\text { occipital cepalocele }\end{array}$ & Unknown & 87 & $\mathrm{~N} / \mathrm{A}$ \\
\hline Faciocardiomelic syndrome & Unknown & 34,35 & N.A \\
\hline Galloway-Mowat syndrome & WDR73 & 69,70 & $\mathrm{~N} / \mathrm{A}$ \\
\hline Gordon syndrome & PIEZO2 & 69,70 & $\mathrm{~N} / \mathrm{A}$ \\
\hline $\begin{array}{l}\text { Proliferative vasculopathy and } \\
\text { hydranencephaly-hydrocephaly } \\
\text { syndrome (PVHH) }\end{array}$ & FLVCR2 & $91,94,95$ & $\mathrm{~N} / \mathrm{A}$ \\
\hline Pseudoaminopterin syndrome & Unknown & 34,35 & $\mathrm{~N} / \mathrm{A}$ \\
\hline $\begin{array}{l}\text { Simpson-Golabi-Behmel syndrome, } \\
\text { type I }\end{array}$ & GPC3 & $34,35,41,42,44,45,64,89$ & $\mathrm{~N} / \mathrm{A}$ \\
\hline Temtamy syndrome & C12ORF57 & 64,65 & $\mathrm{~N} / \mathrm{A}$ \\
\hline
\end{tabular}

N/A, Not applicable.

portion of the upper lip, and the primary palate. Lateral to the FNP are paired maxillary prominences (MXPs) that fuse at the midline with the FNP. The MXPs gives rise to the upper jaw and the sides of the face, the sides of the upper lip, and the secondary palate. Finally, the mandibular prominences (MNPs) fuse and form the base of the stomodium (presumptive mouth), below the FNP. The MNPs give rise to the lower jaw, lower lip, and the anterior portion of the tongue. The development of each of these prominences requires complex interac- tions from different tissue types such as CNCCs, neuroectoderm, surface ectoderm, and pharyngeal endoderm. In this section, we review how each tissue shapes the developing face and comment on how loss of cilia effects the development of each tissue.

\section{Cranial Neural Crest Cells}

CNCCs are a transient population of cells that give rise to a variety of cells types, including the chondrocytes and osteocytes of the facial skel- 




Figure 1. Common features of craniofacial ciliopathies. (A) Frequency of the five craniofacial phenotypes common to craniofacial ciliopathies. (B) Frontal diagram of cleft lip/palate phenotypes. $(C)$ Frontal diagram of the midline defects hypotelorism and hypertelorism. (D) Sagittal diagram of micrognathia. (E) Dorsal view of skulls with multiple types of craniosynostosis. ( F) Frequency of core ciliopathic phenotypes among known craniofacial ciliopathies. a, anterior; $\mathrm{p}$, posterior. eton (Le Douarin et al. 2004). This unique population of cells originates at the dorsal most portion of neural tube, undergoes an epithelial to mesenchymal transition, and migrates toward the developing facial prominences. Throughout their development and migration, CNCCs receive queues from adjacent tissues instructing them to proliferate and/or differentiate (Bhatt et al. 2013). CNCCs can be thought of as the "keystone" of the craniofacial complex, as they sit adjacent to, and participate in, tissue-tissue interactions with all other tissues making up the craniofacial complex.

Primary cilia extend from CNCCs throughout all developmental stages (Schock et al. 2015). Several pieces of data from zebrafish, chick, and mouse ciliopathic models strongly suggest that cilia are required on CNCCs for proper craniofacial development (Tobin et al. 2008; Brugmann et al. 2010; Schock et al. 2015). First, numerous ciliopathic mutants have aberrant CNCC migration characterized by a disorganized actin cytoskeleton, increased cell dispersion, ectopic CNCC migration, and/ or lack of directional persistence (Tobin et al. 2008; Tabler et al. 2013; Schock et al. 2015). Because disrupted CNCC migration is associated with facial clefting (He and Soriano 2013), it is plausible that aberrant CNCC migration contributes to the high frequency of facial clefts observed in ciliopathic patients. Second, loss of primary cilia on CNCCs is often accompanied by dysmorphologies of the CNCC-derived facial skeleton. Patients with oral-facial-digital syndrome frequently present with a cleft secondary palate, micrognathia and underdeveloped cheek bones (zygomatic hypoplasia) due to decreased bone development (Gorlin et al. 1990). Furthermore, cranioectodermal dysplasia patients have multiple skeletal defects with generalized osteopenia (Gorlin et al. 1990). Development of CNCC-derived cartilaginous elements is also aberrant in craniofacial ciliopathies. Both Kif $3 a^{f l / f l} ;$ Wnt1-Cre and Ofd ${ }^{-/-}$ murine mutants have a bifid nasal septum (Brugmann et al. 2010; Khonsari et al. 2013) and facial cartilages are enlarged in the talpid ${ }^{2}$ ciliopathic avian mutant (Schock et al. 2015). 

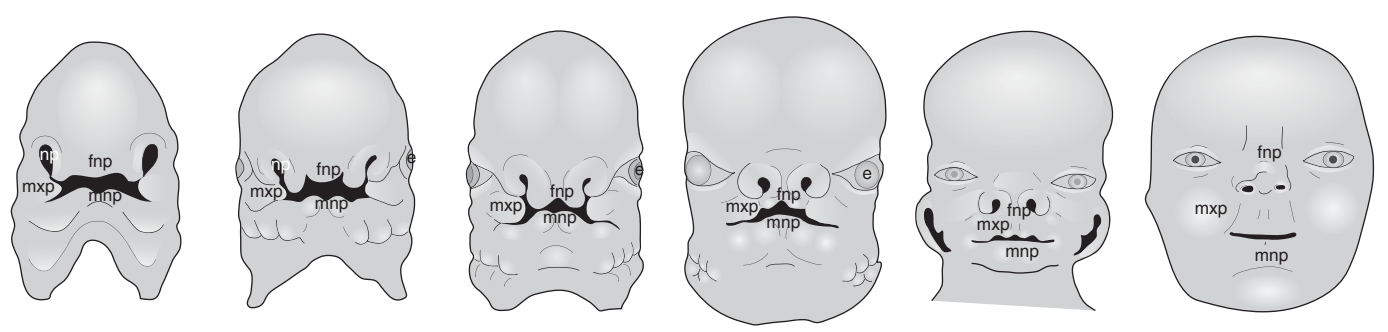

5 Weeks

Figure 2. Human craniofacial development. Diagram showing progression of human craniofacial development beginning at 5 weeks of gestation and ending at 11 weeks of gestation. fnp, Frontonasal prominence; mxp, maxillary prominence; mnp, mandibular prominence; $\mathrm{np}$, nasal pits; e, eye.

Together, these data suggests that primary cilia play an essential role in the regulation of both CNCC migration and differentiation into skeletal elements.

\section{Neuroectoderm}

Several studies have established a strong relationship between the development of the face and brain (Hu and Marcucio 2009a; Chong et al. 2012; Hu et al. 2015; Marcucio et al. 2015). The forebrain structurally supports the developing face and also serves as the source of many signals that are essential for patterning and outgrowth of the facial prominences, specifically the FNP. One of the most important signaling centers for craniofacial development is the ventral forebrain. This region robustly expresses Sonic hedgehog (Shh). When Shh is absent from this region of the brain, the telencephalon fails to develop into two distinct lobes, resulting in holoprosencephaly (Roessler et al. 1996). In many ciliopathic mutants, forebrain development is aberrant. There are several ciliary mouse mutants with forebrain ventralization and shifts in the diencephalon-telencephalon boundary (Tran et al. 2008; Willaredt et al. 2008; Stottmann et al. 2009; Besse et al. 2011). These data indicate that primary cilia play critical roles in early neuroectoderm development and patterning.

Forebrain abnormalities are frequently accompanied by defects in the facial midline. Blocking SHH in the neural tube causes a narrowing of the FNP (Chong et al. 2012). Addi- tionally, the width of Shh domain in the ventral forebrain correlates with midfacial width. Ducks have a wider domain of Shh expression than chickens, and this correlates with a wider midline in ducks (bill vs. beak) (Hu et al. 2015). Although no study has been conducted specifically examining the role of primary cilia in the forebrain to face signaling cascade, one would expect that cilia play a critical role in this process, especially given the high prevalence of hypertelorism as a commonly observed craniofacial phenotype among ciliopathic patients.

\section{Facial Ectoderm}

The facial ectoderm is a thin layer of tissue that covers the surface of the developing facial prominences. Early in craniofacial development, this tissue abuts the neuroectoderm and endoderm; however, migration of CNCCs into the facial prominences causes a separation of tissues. The facial ectoderm contains many localized signaling centers, including the frontonasal ectodermal zone (FEZ) (Hu and Marcucio 2009b) and olfactory ectoderm (Szabo-Rogers et al. 2008). The FEZ is defined by robust Shh expression and is essential for driving facial morphogenesis. The FEZ signals to the underlying CNCC-derived mesenchyme to regulate Bmp expression. Bmps regulate both the shape and size of the upper jaw (Abzhanov et al. 2004; Hu and Marcucio 2009b). The olfactory ectoderm expresses Fgf8, Wnts, and synthesizes retinoic acid. These signals are important for both cra- 
niofacial morphogenesis and skeletal patterning (Song et al. 2004; Szabo-Rogers et al. 2008). Inhibition of fibroblast growth factor (FGF) signaling in the nasal pits results in facial clefting (Szabo-Rogers et al. 2008). The role of cilia on the facial ectoderm that makes up these signaling centers has not been evaluated; however, conditionally knocking out cilia in more specialized facial ectoderm did not affect development of ectodermal-derived structures, such as the teeth (Ohazama et al. 2009). It is possible that this lack of phenotype was due to late onset of recombination. Perhaps ablating cilia in the ectoderm at an earlier time point would prevent the establishment of these key ectodermal signaling centers and result in developmental defects.

\section{Pharyngeal Endoderm}

The pharyngeal endoderm lines the interior aspect of the pharyngeal arches and is the source of signals important for the patterning and proliferation of the lower face and neck. In the absence of pharyngeal endoderm, normal craniofacial development fails to occur indicating that it is an essential component for craniofacial development (Couly et al. 2002). The pharyngeal endoderm supplies the environment with many important signals, including BMPs, FGFs, and SHH (Graham and Smith 2001; Graham 2003). These signals are especially important for instructing CNCC development once they have migrated into the pharyngeal arches (Couly et al. 2002; Walshe and Mason 2003). Most studies on pharyngeal endoderm indicate that the endoderm provides key developmental signals, rather than being the recipient of such signals. The specific role for cilia in the pharyngeal endoderm has not been evaluated; however, endoderm in other areas of the body requires cilia for proper development. In Tmem67 mutant mice, the developing lungs fail to undergo proper epithelial branching morphogenesis (Abdelhamed et al. 2015). Additionally, orpk mice (Ift88 mutant) have an abnormal pancreas characterized by ductal hyperplasia and acinar cell apoptosis (Cano et al. 2004). Together, these data suggest that primary cilia are required for proper development of some endoderm-derived organs.

\section{PRIMARY CILIA AND KEY SIGNALING PATHWAYS IN CRANIOFACIAL DEVELOPMENT}

Proper craniofacial development depends on the integration of multiple signaling pathways in a spatially and temporally regulated manner. The primary cilium serves as a cellular hub for several signaling pathways (Goetz and Anderson 2010), specifically the Hedgehog (Hh) pathway. In the next section, we will review how two major signaling pathways drive craniofacial development and the known or potential roles of primary cilia in the transduction of these pathways.

\section{Hedgehog Signaling and the Primary Cilium}

The correlation between the cilium and Hh signaling is based on two pieces of data. First, receptors for the Hh pathway localize to the primary cilium (Rohatgi et al. 2007). In the absence of an Hh ligand, Patched is localized to the cilium, inhibiting Smoothened entry into the axoneme. Upon binding of an $\mathrm{Hh}$ ligand, Patched-mediated inhibition of Smoothened is alleviated, and Smoothened enters the ciliary axoneme. Second, the transcription factors used to transduce the Hh signal, the Gli family transcription factors, traffic through the ciliary axoneme. In mechanisms still not fully understood, it is believed this trafficking plays a role in converting the full-length Gli proteins into either full-length activators or a cleaved repressor (Haycraft et al. 2005; Huangfu and Anderson 2005). Loss of functional cilia prevents proper Gli processing, frequently resulting in increased levels of full-length Gli and reduced levels of cleaved Gli repressor (Haycraft et al. 2005; Huangfu and Anderson 2005; Liu et al. 2005; May et al. 2005; Hoover et al. 2008; Tran et al. 2008; Willaredt et al. 2008; Chang et al. 2014).

The craniofacial anomalies that result from loss of functional cilia often phenocopy those caused by mutation in the Gli proteins. Greig 
cephalopolysyndactyly syndrome is caused by mutations in GLI3. Individuals with this disease frequently present with polydactyly, syndactyly (digit fusion), macrocephaly, prominent forehead, and hypertelorism. Similarly, PallisterHall syndrome is also caused by mutations in GLI3 and features phenotypes such as polydactyly, syndactyly, hypothalamic hamertomas (benign brain tumor of the hypothalamus), microglossia micrognathia, and cleft palate. Furthermore, mutations in GLI2 are known to cause Culler-Jones syndrome. This disease is characterized by polydactyly, midline facial defects (including holoprosencephaly), and hypopituitarism (Roessler et al. 2003; Franca et al. 2010). Phenotypic presentation of individuals with GLI2 mutations strongly overlaps with those of craniofacial ciliopathies, including the frequent occurrence of dysmorphic and displaced pituitary glands (Khonsari et al. 2013). Although there is not a complete phenotypic overlap between diseases caused by Gli mutations and ciliopathies, there are numerous parallels. The discovery that primary cilia regulate Shh signaling via Gli protein processing explains the phenotypic overlap between ciliopathies and diseases caused by mutation in Gli proteins.

Common Craniofacial Ciliopathic Phenotypes Are Linked to Defects in Shh Signaling

Cleft lip/palate is one of the most common congenital defects, with an occurrence of one in every 500-750 live births (see cdc.gov/ NCBDDD/birthdefects/facts.html). Clefting is also the most common defect in craniofacial ciliopathies, with $45 \%$ of craniofacial ciliopathies presenting with the condition (Fig. 1A). Clefting occurs when there is a failure of two or more facial prominences to fuse. Onset of clefting of either the lip or palate can result from aberrant cell migration, proliferation, or fusion. Spatial and temporal regulation of multiple signaling pathways is essential for normal palatogenesis. Shh is expressed in the epithelium of the developing palate in a series of stripes known as rugae and plays critical roles in induction of Fgf10 and Foxf1/2 in the palatal mesenchyme.
These factors promote mesenchymal proliferation and also work through intermediates to regulate Shh expression in the epithelium. When Shh or these downstream pathway targets are lost, a cleft in the secondary palate occurs (Cobourne and Green 2012; Xu et al. 2016). Clefting may also be secondary to other facial anomalies that alter the width or growth of the face. For example, a widened midline may prevent the MXPs from being able to fuse to form the secondary palate. Given the requirement for complex tissue-tissue interactions and the intricacies of signaling networks during palatogenesis, it is likely that ciliary-dependent $\mathrm{Hh}$ signaling is necessary for proper palatogenesis.

The Hh pathway is undisputedly the pathway most closely associated with aberrant midline patterning ( $\mathrm{Hu}$ and Helms 1999) due to ligand expression in key signal centers, such as the ventral neuroectoderm and FEZ. In the simplest of terms, loss of Hh signaling results in a reduced or collapsed midline (hypotelorism, cyclopia), whereas gain of Hh activity causes an expanded midline (hypertelorism) (Chiang et al. 1996) or, in severe instances, facial duplication (Hu and Helms 1999). These data strongly indicate that levels of Shh are a key determinant of midfacial width. Several ciliary mutants with aberrant Shh signaling present with midfacial defects, strongly suggesting midfacial development, requires ciliary-dependent Hh signaling (Buxton et al. 2004; May et al. 2005; Beales et al. 2007; Gorivodsky et al. 2009; Brugmann et al. 2010). Currently, it is not understood why some ciliary mutations result in a loss of Hh function, whereas others result in a gain of Hh function.

Micrognathia occurs in almost 20\% of craniofacial ciliopathies. Jaw deficiencies can be caused by a number of things, including failure of CNCCs to migrate and populate the MNP, aberrant CNCC differentiation into skeletal elements, or disruptions in molecular signaling. Defects in the Hh signaling pathway have been associated with the onset of micrognathia. Early in craniofacial development, the oral ectoderm and pharyngeal endoderm express Shh. Expression of Shh in these domains is required for CNCC survival within the MNP (Billmyre and 
Klingensmith 2015). Increased death of CNCC in the MNP reduces the pool of skeletal progenitors, thus resulting in micrognathia. Additionally, at slightly later stages, Shh from the mandibular epithelium directs early differentiation of mandibular chondrogenic elements, such as Meckel's cartilage (Billmyre and Klingensmith 2015). Once again, aberrant mandibular chondrogenesis could ultimately manifest as micrognathia. Disruptions in ciliary-dependent $\mathrm{Hh}$ signaling at either of these stages of mandibular development could lead to severe micrognathia.

Finally, craniosysnostosis presents in a modest $7 \%$ of known craniofacial ciliopathies. Craniosynostosis is most commonly associated with mutations in Twist transcription factors (Howard et al. 1997) and members of the FGF signaling pathway (Muenke and Schell 1995; Rice et al. 2000), which may explain why this is not a prevalent phenotype in ciliopathy patients. Recent studies have investigated potential roles for Hh signaling in suture maintenance and calvaria formation. Gli1-positive cells reside at the sutures in postnatal mice and Indian Hedgehog (Ihh) promotes the differentiation of these cells into craniofacial bones, dura, periosteum and the osteogenic front (Zhao et al. 2015). Given these newly identified roles for $\mathrm{Hh}$ signaling in suture formation and maintenance, it is quite possible that cilia may be playing a role in this process as well.

Craniofacial ciliopathies are often paired with defects in the brain (Fig. 1F). A long-asked question in developmental biology is does the face predict the brain? Or the converse question of does the brain predict the face? Given the high correlation between brain and face phenotypes observed in ciliopathies, it is likely that the relationship between brain and face development is not unidirectional, but rather the development of one affects the development of the other. Similar to what is observed in the face, most of the brain phenotypes found in ciliopathic models are specific to the midline of the brain. Agenesis of the corpus callosum, defects in dopaminergic neurogenesis at the midbrain midline, aberrant hippocampal neurogenesis, and hypoplasia of the cerebellum are all midline brain defects that have been identi- fied in ciliopathic models (Breunig et al. 2008; Han et al. 2008; Laclef et al. 2015; Schock et al. 2015; Gazea et al. 2016). Given that Shh is expressed throughout the midline of the brain, it is not surprising that many of the above phenotypes have been attributed to defective ciliadependent Hh signaling.

\section{An Alternative to Hh-Mediated Ciliopathic Facial Phenotypes: Wnt Signaling during Craniofacial Development}

The Wnt pathway represents one of the major developmental signaling pathways regulating several cellular processes, including cell proliferation, determination, differentiation, and survival (reviewed in Cadigan and Nusse 1997). In terms of craniofacial development, the Wnt pathway is required at several crucial time points and for the specialization of numerous craniofacial features (midface, oral cavity, facial skeleton, etc.). Most notably, Wnt signaling plays an important role in the generation and migration of CNCCs (Schmidt and Patel 2005; Basch and Bronner-Fraser 2006), and the development, regionalization, and species-specification of the face (Brugmann et al. 2007). As shown by various Wnt reporter mice (BAT-gal and TOP-gal) (DasGupta and Fuchs 1999; Maretto et al. 2003), Wnt pathway activity is localized to facial ectoderm and the underlying mesenchyme in the lateral nasal prominence, MXP and MNP.

Relative to the Hh pathway, much less is known regarding cilium-dependent transduction of a Wnt signal. There are several contradictory reports regarding the nature of the relationship between Wnt and primary cilia. Some reports suggest a requirement for cilia in Wnt signal transduction (Otto et al. 2003; Watanabe et al. 2003; Simons et al. 2005; Corbit et al. 2008; Tran et al. 2008; McDermott et al. 2010; Lienkamp et al. 2012). Many of these studies support the idea that the cilia or cilia-related proteins play a role in restraining a Wnt signal, albeit in a mechanism that is not fully understood. Other studies, however, suggest that loss of cilia does not have an effect on Wnt signaling (Huang and Schier 2009; Ocbina et al. 2009; 
Brugmann et al. 2010). Several explanations exist for these seemingly contradictory results, including spatial and/or temporal gene expression differences and species specificity. Finally, and not mutually exclusive from the other possibilities, these contradictory findings could be the result of examining mutations in different classes of ciliary proteins. Thus, different results could be acquired depending on whether an axonemal, transition zone, or basal body protein was mutated.

More recently, numerous studies have addressed how the primary cilium may coordinate the balance between canonical and noncanonical Wnt signaling during development and in tissue homeostasis (Wallingford and Mitchell 2011; Oh and Katsanis 2013). Localization of the Wnt signaling component Inversin at the base of the cilium is hypothesized to act as a molecular switch between canonical and noncanonical/PCP signaling (Otto et al. 2003; Watanabe et al. 2003; Simons et al. 2005). The link between the cilium and noncanonical/PCP continues to grow. Loss of several ciliary proteins causes phenotypes indicative of a PCP mutation (Ross et al. 2005; Gerdes et al. 2007; May-Simera et al. 2010). Yet, despite the fact that cilia and/or some cilia-related proteins can influence planar cell polarization, the mechanism of how PCP signaling and ciliary function are related remains a "black box."

Several facial phenotypes associated with craniofacial ciliopathies also result from defects in Wnt signaling. Susceptibility to clefting is linked to disruptions in various Wnt genes ( Juriloff et al. 1996, 2001, 2005) and disruptions to the Wnt pathway produce mild to severe facial clefting in both animal models and human patients (Miller et al. 2006; Brugmann et al. 2007; Chiquet et al. 2008; Song et al. 2009; Ferretti et al. 2011). Most Wnt-related clefting defects arise in one of two ways: CNCC insufficiency or a lack of fusion between facial prominences. First, CNCC insufficiency is common in Wnt mutants because Wnts promote proliferation of CNCC-derived mesenchyme, and subsequent growth of the facial prominences (Brugmann et al. 2007). Loss of Wnt activity in this tissue results in hypoplastic prominences which fail to abut one another, causing a wide cleft. Second, failure of fusion is common in Wnt mutants, as multiple Wnt ligands are expressed in the facial ectoderm and essential for the fusion of facial prominences (Lan et al. 2006; Geetha-Loganathan et al. 2009; Song et al. 2009). Based on the roles for both Wnt and cilia in these cellular processes, it is not difficult to hypothesize that onset of clefting in craniofacial ciliopathies is caused by a defect in cilia-dependent Wnt signaling.

In addition to clefting, both micrognathia and hypertelorism are common phenotypes in Wnt signaling defects. Based on the suggested role for Wnt in promoting mesenchymal proliferation in both the MXP and MNP, it is not difficult to imagine how a disruption in the pathway could lead to reduced growth of the upper and lower jaw. Disruptions to Wnt signaling in the ectoderm also result in ciliopathic craniofacial phenotypes. Loss of $\beta$-catenin causes loss of CNCC-derived bone and ectopic facial cartilages (Reid et al. 2011). These data indicate that $\mathrm{Wnt} / \beta$-catenin signaling within the ectoderm is critical for facial development. Determining whether the onset of these ciliopathic craniofacial phenotypes is due to ciliarydependent Wnt signaling will be an important future step in formulating potential therapeutic treatments.

\section{CONCLUSIONS}

Our analyses revealed the most common phenotypes present in craniofacial ciliopathies are cleft lip/palate, hyper-/hypotelorism, micrognathia, and craniosynostosis. With this information in hand, it is worthwhile to reexamine "orphan" craniofacial anomalies with no known genetic cause for defects in ciliary proteins. Performing array analysis for known ciliary genes or examining ciliary extension on cells from patients that present with phenotypes typical of a craniofacial ciliopathy could greatly inform diagnosis and provide a novel manner to examine craniofacial anomalies with no known genetic cause.

Ciliopathies are not simply a class of diseases in which only one organ or organ system 
is affected; they are multifaceted and ciliopathic individuals often present with multiple phenotypes. The face is a prime example of the myriad of phenotypes that can be present within a single ciliopathy. Perhaps this is due to a high dependence on tissue-tissue interactions during craniofacial development. Whether signaling between tissues is unidirectional or bidirectional, it stands to reason that primary cilia may be key mediators of developmental processes that require tissue-tissue interactions. Understanding the mechanism by which signaling pathways are propagated through the primary cilium will help us to understand how specific phenotypes arise.

\section{ACKNOWLEDGMENTS}

Data reviewed in this work is supported by grants from the National Institutes of Health $(\mathrm{NIH}) /$ National Institute of Dental and Craniofacial Research (NIDCR) R01DE023804 (S.A.B.) and F31DE025537 (E.N.S).

\section{REFERENCES}

Abdelhamed ZA, Natarajan S, Wheway G, Inglehearn CF, Toomes C, Johnson CA, Jagger DJ. 2015. The MeckelGruber syndrome protein TMEM67 controls basal body positioning and epithelial branching morphogenesis in mice via the non-canonical Wnt pathway. Dis Model Mech 8: 527-541.

Abzhanov A, Protas M, Grant RB, Grant PR, Tabin CJ. 2004. Bmp4 and morphological variation of beaks in Darwin's finches. Science 305: 1462-1465.

Baker K, Beales P. 2009. Making sense of cilia in disease: The human ciliopathies. Am J Med Genet 151C: 281-295.

Basch ML, Bronner-Fraser M. 2006. Neural crest inducing signals. Adv Exp Med Biol 589: 24-31.

Beales PL, Bland E, Tobin JL, Bacchelli C, Tuysuz B, Hill J, Rix S, Pearson CG, Kai M, Hartley J, et al. 2007. IFT80, which encodes a conserved intraflagellar transport protein, is mutated in Jeune asphyxiating thoracic dystrophy. Nat Genet 39: 727-729.

Besse L, Neti M, Anselme I, Gerhardt C, Ruther U, Laclef C, Schneider-Maunoury S. 2011. Primary cilia control telencephalic patterning and morphogenesis via Gli3 proteolytic processing. Development 138: 2079-2088.

Bhatt S, Diaz R, Trainor PA. 2013. Signals and switches in mammalian neural crest cell differentiation. Cold Spring Harb Perspect Biol 5: a008326.

Billmyre KK, Klingensmith J. 2015. Sonic Hedgehog from pharyngeal arch 1 epithelium is necessary for early mandibular arch cell survival and later cartilage condensation differentiation. Dev Dyn 244: 564-576.
Breunig JJ, Sarkisian MR, Arellano JI, Morozov YM, Ayoub AE, Sojitra S, Wang B, Flavell RA, Rakic P, Town T. 2008. Primary cilia regulate hippocampal neurogenesis by mediating sonic hedgehog signaling. Proc Natl Acad Sci 105: 13127-13132.

Brugmann SA, Goodnough LH, Gregorieff A, Leucht P, ten Berge D, Fuerer C, Clevers H, Nusse R, Helms JA. 2007. Wnt signaling mediates regional specification in the vertebrate face. Development 134: 3283-3295.

Brugmann SA, Allen NC, James AW, Mekonnen Z, Madan E, Helms JA. 2010. A primary cilia-dependent etiology for midline facial disorders. Hum Mol Genet 19: 1577-1592.

Buxton P, Davey MG, Paton IR, Morrice DR, Francis-West PH, Burt DW, Tickle C. 2004. Craniofacial development in the talpid3 chicken mutant. Differentiation 72: 348362.

Cadigan KM, Nusse R. 1997. Wnt signaling: A common theme in animal development. Genes Dev 11: 32863305.

Cano DA, Murcia NS, Pazour GJ, Hebrok M. 2004. Orpk mouse model of polycystic kidney disease reveals essential role of primary cilia in pancreatic tissue organization. Development 131: 3457-3467.

Chang CF, Schock EN, O’Hare EA, Dodgson J, Cheng HH, Muir WM, Edelmann RE, Delany ME, Brugmann SA. 2014. The cellular and molecular etiology of the craniofacial defects in the avian ciliopathic mutant talpid2. Development 141: 3003-3012.

Chiang C, Litingtung Y, Lee E, Young KE, Corden JL, Westphal H, Beachy PA. 1996. Cyclopia and defective axial patterning in mice lacking Sonic Hedgehog gene function. Nature 383: 407-413.

Chiquet BT, Blanton SH, Burt A, Ma D, Stal S, Mulliken JB, Hecht JT. 2008. Variation in WNT genes is associated with non-syndromic cleft lip with or without cleft palate. Hum Mol Genet 17: 2212-2218.

Chong HJ, Young NM, Hu D, Jeong J, McMahon AP, Hallgrimsson B, Marcucio RS. 2012. Signaling by $\mathrm{SHH}$ rescues facial defects following blockade in the brain. Dev Dyn 241: 247-256.

Cobourne MT, Green JB. 2012. Hedgehog signalling in development of the secondary palate. Front Oral Biol 16: 52-59.

Corbit KC, Shyer AE, Dowdle WE, Gaulden J, Singla V, Chen MH, Chuang PT, Reiter JF. 2008. Kif3a constrains $\beta$-catenin-dependent Wnt signalling through dual ciliary and non-ciliary mechanisms. Nat Cell Biol 10: 70-76.

Couly G, Creuzet S, Bennaceur S, Vincent C, Le Douarin NM. 2002. Interactions between Hox-negative cephalic neural crest cells and the foregut endoderm in patterning the facial skeleton in the vertebrate head. Development 129: $1061-1073$.

DasGupta R, Fuchs E. 1999. Multiple roles for activated LEF/TCF transcription complexes during hair follicle development and differentiation. Development 126: 4557-4568.

Ferretti E, Li B, Zewdu R, Wells V, Hebert JM, Karner C, Anderson MJ, Williams T, Dixon J, Dixon MJ, et al. 2011. A conserved Pbx-Wnt-p63-Irf6 regulatory module controls face morphogenesis by promoting epithelial apoptosis. Dev Cell 21: 627-641. 
Franca MM, Jorge AA, Carvalho LR, Costalonga EF, Vasques GA, Leite CC, Mendonca BB, Arnhold IJ. 2010. Novel heterozygous nonsense GLI2 mutations in patients with hypopituitarism and ectopic posterior pituitary lobe without holoprosencephaly. J Clin Endocrinol Metab 95: E384-E391.

Gazea M, Tasouri E, Tolve M, Bosch V, Kabanova A, Gojak C, Kurtulmus B, Novikov O, Spatz J, Pereira G, et al. 2016 Primary cilia are critical for Sonic hedgehog-mediated dopaminergic neurogenesis in the embryonic midbrain. Devel Biol 409: 55-71.

Geetha-Loganathan P, Nimmagadda S, Antoni L, Fu K, Whiting CJ, Francis-West P, Richman JM. 2009. Expression of WNT signalling pathway genes during chicken craniofacial development. Dev Dyn 238: 1150-1165.

Gerdes JM, Liu Y, Zaghloul NA, Leitch CC, Lawson SS, Kato M, Beachy PA, Beales PL, DeMartino GN, Fisher S, et al. 2007. Disruption of the basal body compromises proteasomal function and perturbs intracellular Wnt response. Nat Genet 39: 1350-1360.

Goetz SC, Anderson KV. 2010. The primary cilium: A signalling centre during vertebrate development. Nat Rev Genet 11: 331-344.

Gorivodsky M, Mukhopadhyay M, Wilsch-Braeuninger M, Phillips M, Teufel A, Kim C, Malik N, Huttner W, Westphal H. 2009. Intraflagellar transport protein 172 is essential for primary cilia formation and plays a vital role in patterning the mammalian brain. Devel Biol 325: 24-32.

Gorlin RJ, Cohen MM, Levin LS. 1990. Syndromes of the head and neck. Oxford University Press, New York.

Graham A. 2003. Development of the pharyngeal arches. Am J Med Genet 119A: 251-256.

Graham A, Smith A. 2001. Patterning the pharyngeal arches. Bioessays 23: 54-61.

Han YG, Spassky N, Romaguera-Ros M, Garcia-Verdugo JM, Aguilar A, Schneider-Maunoury S, Alvarez-Buylla A. 2008. Hedgehog signaling and primary cilia are required for the formation of adult neural stem cells. Nat Neurosci 11: 277-284.

Haycraft CJ, Banizs B, Aydin-Son Y, Zhang Q, Michaud EJ, Yoder BK. 2005. Gli2 and Gli3 localize to cilia and require the intraflagellar transport protein polaris for processing and function. PLoS Genet 1: e53.

He F, Soriano P. 2013. A critical role for PDGFR $\alpha$ signaling in medial nasal process development. PLoS Genet 9: e1003851.

Hoover AN, Wynkoop A, Zeng H, Jia J, Niswander LA, Liu A. 2008. $\mathrm{C} 2 \mathrm{~cd} 3$ is required for cilia formation and Hedgehog signaling in mouse. Development 135: 4049-4058.

Howard TD, Paznekas WA, Green ED, Chiang LC, Ma N, Ortiz de Luna RI, Garcia Delgado C, Gonzalez-Ramos M, Kline AD, Jabs EW. 1997. Mutations in TWIST, a basic helix-loop-helix transcription factor, in Saethre-Chotzen syndrome. Nat Genet 15: 36-41.

Hu D, Helms JA. 1999. The role of sonic hedgehog in normal and abnormal craniofacial morphogenesis. Development 126: $4873-4884$.

Hu D, Marcucio RS. 2009a. A SHH-responsive signaling center in the forebrain regulates craniofacial morphogenesis via the facial ectoderm. Development 136: 107-116.
Hu D, Marcucio RS. 2009b. Unique organization of the frontonasal ectodermal zone in birds and mammals. Dev Biol 325: 200-210.

Hu D, Young NM, Xu Q, Jamniczky H, Green RM, Mio W, Marcucio RS, Hallgrimsson B. 2015. Signals from the brain induce variation in avian facial shape. Dev Dyn doi: $10.1002 /$ dvdy.24284.

Huang P, Schier AF. 2009. Dampened Hedgehog signaling but normal Wnt signaling in zebrafish without cilia. Development 136: 3089-3098.

Huangfu D, Anderson KV. 2005. Cilia and Hedgehog responsiveness in the mouse. Proc Natl Acad Sci 102: 11325-11330.

Juriloff DM, Harris MJ, Mah DG. 1996. The clf1 gene maps to a 2- to 3-cM region of distal mouse chromosome 11. Mamm Genome 7: 789.

Juriloff DM, Harris MJ, Brown CJ. 2001. Unravelling the complex genetics of cleft lip in the mouse model. Mamm Genome 12: 426-435.

Juriloff DM, Harris MJ, Dewell SL, Brown CJ, Mager DL, Gagnier L, Mah DG. 2005. Investigations of the genomic region that contains the clf1 mutation, a causal gene in multifactorial cleft lip and palate in mice. Birth Defects Res A Clin Mol Teratol 73: 103-113.

Khonsari RH, Seppala M, Pradel A, Dutel H, Clement G, Lebedev O, Ghafoor S, Rothova M, Tucker A, Maisey JG, et al. 2013. The buccohypophyseal canal is an ancestral vertebrate trait maintained by modulation in sonic hedgehog signaling. BMC Biol 11: 27.

Laclef C, Anselme I, Besse L, Catala M, Palmyre A, Baas D, Paschaki M, Pedraza M, Metin C, Durand B, SchneiderMaunoury S. 2015. The role of primary cilia in corpus callosum formation is mediated by production of the Gli3 repressor. Hum Mol Genet 24: 4997-5014.

Lan Y, Ryan RC, Zhang Z, Bullard SA, Bush JO, Maltby KM, Lidral AC, Jiang R. 2006. Expression of Wnt $9 b$ and activation of canonical Wnt signaling during midfacial morphogenesis in mice. Dev Dyn 235: 1448-1454.

Le Douarin NM, Creuzet S, Couly G, Dupin E. 2004. Neural crest cell plasticity and its limits. Development 131: 4637 4650.

Lienkamp S, Ganner A, Walz G. 2012. Inversin, Wnt signaling and primary cilia. Differentiation 83: S49-S55.

Liu A, Wang B, Niswander LA. 2005. Mouse intraflagellar transport proteins regulate both the activator and repressor functions of Gli transcription factors. Development 132: $3103-3111$.

Marcucio R, Hallgrimsson B, Young NM. 2015. Facial morphogenesis: Physical and molecular interactions between the brain and the face. Curr Topics Dev Biol 115: 299-320.

Maretto S, Cordenonsi M, Dupont S, Braghetta P, Broccoli V, Hassan AB, Volpin D, Bressan GM, Piccolo S. 2003. Mapping Wnt/ $\beta$-catenin signaling during mouse development and in colorectal tumors. Proc Natl Acad Sci 100: 3299-3304.

May SR, Ashique AM, Karlen M, Wang B, Shen Y, Zarbalis K, Reiter J, Ericson J, Peterson AS. 2005. Loss of the retrograde motor for IFT disrupts localization of Smo to cilia and prevents the expression of both activator and repressor functions of Gli. Dev Biol 287: 378-389. 
E.N. Schock and S.A. Brugmann

May-Simera HL, Kai M, Hernandez V, Osborn DP, Tada M, Beales PL. 2010. Bbs8, together with the planar cell polarity protein Vangl2, is required to establish left-right asymmetry in zebrafish. Dev Biol 345: 215-225.

McDermott KM, Liu BY, Tlsty TD, Pazour GJ. 2010. Primary cilia regulate branching morphogenesis during mammary gland development. Curr Biol 20: 731-737.

Miller LA, Smith AN, Taketo MM, Lang RA. 2006. Optic cup and facial patterning defects in ocular ectoderm $\beta$-catenin gain-of-function mice. BMC Dev Biol 6: 14 .

Muenke M, Schell U. 1995. Fibroblast-growth-factor receptor mutations in human skeletal disorders. Trends Genet 11: $308-313$.

Ocbina PJ, Tuson M, Anderson KV. 2009. Primary cilia are not required for normal canonical Wnt signaling in the mouse embryo. PLoS ONE 4: e6839.

Oh EC, Katsanis N. 2013. Context-dependent regulation of Wnt signaling through the primary cilium. J Am Soc Nephrol 24: 10-18.

Ohazama A, Haycraft CJ, Seppala M, Blackburn J, Ghafoor S, Cobourne M, Martinelli DC, Fan CM, Peterkova R, Lesot H, et al. 2009. Primary cilia regulate Shh activity in the control of molar tooth number. Development 136: 897-903.

Otto EA, Schermer B, Obara T, O’Toole JF, Hiller KS, Mueller AM, Ruf RG, Hoefele J, Beekmann F, Landau D, et al. 2003. Mutations in INVS encoding inversin cause nephronophthisis type 2, linking renal cystic disease to the function of primary cilia and left-right axis determination. Nat Genet 34: 413-420.

Reid BS, Yang H, Melvin VS, Taketo MM, Williams T. 2011. Ectodermal $W n t / \beta$-catenin signaling shapes the mouse face. Dev Biol 349: 261-269.

Rice DP, Aberg T, Chan Y, Tang Z, Kettunen PJ, Pakarinen L, Maxson RE, Thesleff I. 2000. Integration of FGF and TWIST in calvarial bone and suture development. Development 127: 1845-1855.

Roessler E, Belloni E, Gaudenz K, Jay P, Berta P, Scherer SW, Tsui LC, Muenke M. 1996. Mutations in the human Sonic Hedgehog gene cause holoprosencephaly. Nat Genet 14: 357-360.

Roessler E, Du YZ, Mullor JL, Casas E, Allen WP, GillessenKaesbach G, Roeder ER, Ming JE, Ruiz i Altaba A, Muenke M. 2003. Loss-of-function mutations in the human GLI2 gene are associated with pituitary anomalies and holoprosencephaly-like features. Proc Natl Acad Sc 100: $13424-13429$.

Rohatgi R, Milenkovic L, Scott MP. 2007. Patched1 regulates hedgehog signaling at the primary cilium. Science 317: 372-376.

Ross AJ, May-Simera H, Eichers ER, Kai M, Hill J, Jagger DJ, Leitch CC, Chapple JP, Munro PM, Fisher S, et al. 2005. Disruption of Bardet-Biedl syndrome ciliary proteins perturbs planar cell polarity in vertebrates. Nat Genet 37: 1135-1140.

Schmidt C, Patel K. 2005. Wnts and the neural crest. Anat Embryol 209: 349-355.

Schock EN, Chang CF, Struve JN, Chang YT, Chang J, Delany ME, Brugmann SA. 2015. Using the avian mutant talpid2 as a disease model for understanding the oral- facial phenotypes of oral-facial-digital syndrome. Dis Models Mech 8: 855-866.

Simons M, Gloy J, Ganner A, Bullerkotte A, Bashkurov M, Kronig C, Schermer B, Benzing T, Cabello OA, Jenny A, et al. 2005. Inversin, the gene product mutated in nephronophthisis type II, functions as a molecular switch between Wnt signaling pathways. Nat Genet 37: 537-543.

Song Y, Hui JN, Fu KK, Richman JM. 2004. Control of retinoic acid synthesis and FGF expression in the nasal pit is required to pattern the craniofacial skeleton. Dev Biol 276: 313-329.

Song L, Li Y, Wang K, Wang YZ, Molotkov A, Gao L, Zhao T, Yamagami T, Wang Y, Gan Q, et al. 2009. Lrp6-mediated canonical Wnt signaling is required for lip formation and fusion. Development 136: 3161-3171.

Stottmann RW, Tran PV, Turbe-Doan A, Beier DR. 2009. $T t c 21 b$ is required to restrict sonic hedgehog activity in the developing mouse forebrain. Dev Biol 335: 166-178.

Szabo-Rogers HL, Geetha-Loganathan P, Nimmagadda S, Fu KK, Richman JM. 2008. FGF signals from the nasal pit are necessary for normal facial morphogenesis. Dev Biol 318: 289-302.

Tabler JM, Barrell WB, Szabo-Rogers HL, Healy C, Yeung Y, Perdiguero EG, Schulz C, Yannakoudakis BZ, Mesbahi A, Wlodarczyk B, et al. 2013. Fuz mutant mice reveal shared mechanisms between ciliopathies and FGF-related syndromes. Dev Cell 25: 623-635.

Tobin JL, Di Franco M, Eichers E, May-Simera H, Garcia M, Yan J, Quinlan R, Justice MJ, Hennekam RC, Briscoe J, et al. 2008. Inhibition of neural crest migration underlies craniofacial dysmorphology and Hirschsprung's disease in Bardet-Biedl syndrome. Proc Natl Acad Sci 105: 6714-6719.

Tran PV, Haycraft CJ, Besschetnova TY, Turbe-Doan A, Stottmann RW, Herron BJ, Chesebro AL, Qiu H, Scherz PJ, Shah JV, et al. 2008. THM1 negatively modulates mouse sonic hedgehog signal transduction and affects retrograde intraflagellar transport in cilia. Nat Genet 40: 403-410.

Wallingford JB, Mitchell B. 2011. Strange as it may seem: The many links between Wnt signaling, planar cell polarity, and cilia. Genes Dev 25: 201-213.

Walshe J, Mason I. 2003. Fgf signalling is required for formation of cartilage in the head. Dev Biol 264: 522-536.

Watanabe D, Saijoh Y, Nonaka S, Sasaki G, Ikawa Y, Yokoyama T, Hamada H. 2003. The left-right determinant Inversin is a component of node monocilia and other $9+0$ cilia. Development 130: 1725-1734.

Willaredt MA, Hasenpusch-Theil K, Gardner HA, Kitanovic I, Hirschfeld-Warneken VC, Gojak CP, Gorgas K, Bradford CL, Spatz J, Wolfl S, et al. 2008. A crucial role for primary cilia in cortical morphogenesis. J Neurosci 28: 12887-12900.

Xu J, Liu H, Lan Y, Aronow BJ, Kalinichenko VV, Jiang R. 2016. A Shh-Foxf-Fgf18-Shh molecular circuit regulating palate development. PLoS Genet 12: e1005769.

Zaghloul NA, Brugmann SA. 2011. The emerging face of primary cilia. Genesis 49: 231-246.

Zhao H, Feng J, Ho TV, Grimes W, Urata M, Chai Y. 2015. The suture provides a niche for mesenchymal stem cells of craniofacial bones. Nat Cell Biol 17: 386-396. 


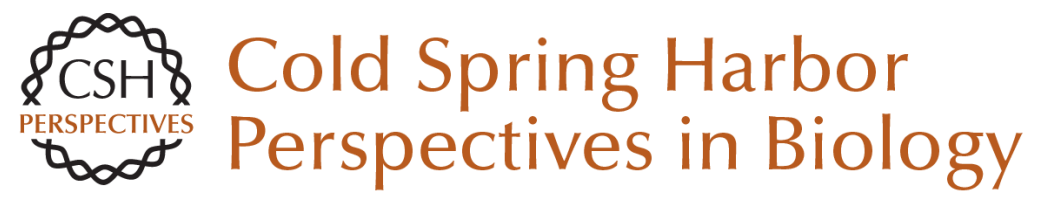

\section{Discovery, Diagnosis, and Etiology of Craniofacial Ciliopathies}

Elizabeth N. Schock and Samantha A. Brugmann

Cold Spring Harb Perspect Biol 2017; doi: 10.1101/cshperspect.a028258 originally published online February 17, 2017

\section{Subject Collection Cilia}

Ciliary Mechanisms of Cyst Formation in Polycystic Kidney Disease

Ming Ma, Anna-Rachel Gallagher and Stefan Somlo

Photoreceptor Cilia and Retinal Ciliopathies Kinga M. Bujakowska, Qin Liu and Eric A. Pierce

G-Protein-Coupled Receptor Signaling in Cilia Kirk Mykytyn and Candice Askwith

Evolution of Cilia David R. Mitchell

Transition Zone Migration: A Mechanism for Cytoplasmic Ciliogenesis and Postaxonemal Centriole Elongation

Tomer Avidor-Reiss, Andrew Ha and Marcus L. Basiri

Cilia and Obesity

Christian Vaisse, Jeremy F. Reiter and Nicolas F. Berbari

Posttranslational Modifications of Tubulin and Cilia

Dorota Wloga, Ewa Joachimiak, Panagiota Louka, et al.
Cilia in Left-Right Symmetry Breaking Kyosuke Shinohara and Hiroshi Hamada

Discovery, Diagnosis, and Etiology of Craniofacial Ciliopathies Elizabeth N. Schock and Samantha A. Brugmann

Axoneme Structure from Motile Cilia Takashi Ishikawa

Cilia and Ciliopathies in Congenital Heart Disease Nikolai T. Klena, Brian C. Gibbs and Cecilia W. Lo

Sperm Sensory Signaling Dagmar Wachten, Jan F. Jikeli and U. Benjamin Kaupp

\section{Primary Cilia and Coordination of Receptor} Tyrosine Kinase (RTK) and Transforming Growth Factor $\beta$ (TGF- $\beta$ ) Signaling Søren T. Christensen, Stine K. Morthorst, Johanne B. Mogensen, et al.

Primary Cilia and Mammalian Hedgehog Signaling Fiona Bangs and Kathryn V. Anderson

For additional articles in this collection, see http://cshperspectives.cshlp.org/cgi/collection/

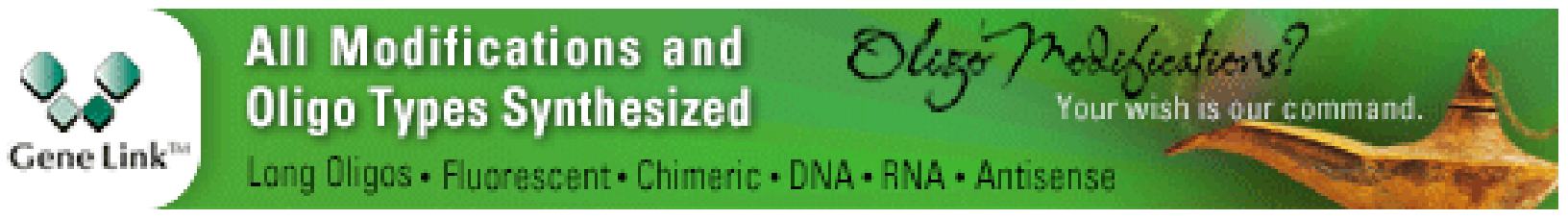


Radial Spokes--A Snapshot of the Motility Regulation, Assembly, and Evolution of Cilia and Flagella

Xiaoyan Zhu, Yi Liu and Pinfen Yang
Cilia and Mucociliary Clearance

Ximena M. Bustamante-Marin and Lawrence E. Ostrowski

For additional articles in this collection, see http://cshperspectives.cshlp.org/cgi/collection/

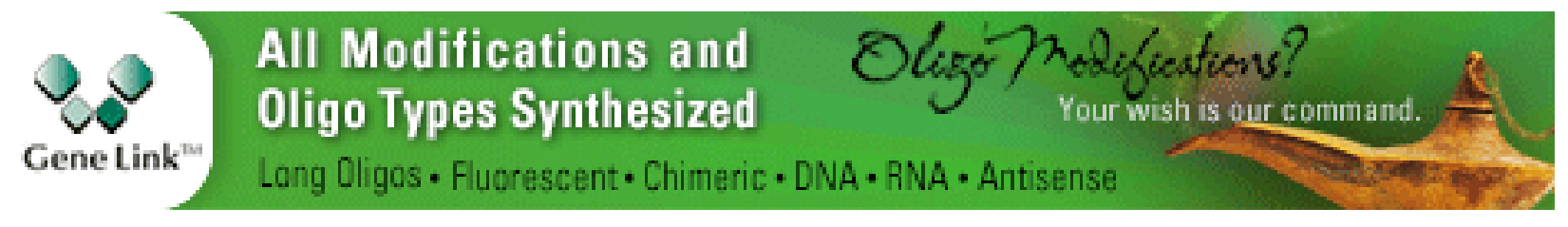

Copyright @ 2017 Cold Spring Harbor Laboratory Press; all rights reserved 